\title{
PEMBAHARUAN SISTEM PENDIDIKAN PESANTREN DAN STRATEGI BERTAHANNYA, MENUJU PESANTREN IDAMAN MASA DEPAN DALAM MENGHADAPI TANTANGAN GLOBALISASI
}

\author{
Husnul Amin \\ Sekolah Tinggi Ilmu Tarbiyah Raudhatul Ulum Sakatiga \\ Email: husnulamin@stit-ru.ac.id
}

\begin{abstract}
Abstrak
Salah satu di antara ciri-ciri komunitas masyarakat adalah adanya perubahan yang kontinyu, selalu mengalami dinamika dan perkembangan dikarenakan tuntutan zaman. Termasuk di dalamnya Pesantren. Penelitian ini membahas tentang pembaharuan system pendidikan pesantren dan strategi bertahannya, menuju pesantren idaman masa depan dalam menghadapi globalisasi. Dengan tujuan untuk merumuskan strategi yang diperlukan untuk menghadapinya. Hasil penelitian ini memperlihatkan bahwa kunci bertahannya pesantren dan stategi untuk tetap eksis dalam menghadapi tantangan globalisasi adalah pembaharuan terhadap aspek atau komponen pendidikannya
\end{abstract}

Kata Kunci: Pembaharuan, Pendidikan Pesantren, Strategi, Globalisasi

\section{Pendahuluan}

Salah satu di antara ciri-ciri komunitas masyarakat adalah adanya perubahan yang kontinyu, selalu mengalami dinamika dan perkembangan dikarenakan tuntutan zaman. Perkembangan yang dimaksud adalah perkembangan dalam berbagai bidang kehidupan,di antaranya perkembangan teknologi, ilmu pengetahuan, ekonomi, politik, ideologi, estetika dan nilai-nilai etika sehingga terjadi perubahan dengan pesat. Menurut Abraham Maslow, terjadinya perubahan dikarenakan adanya motivasi (Maslow, 1994: 31). Jadi motivasi yang membuat orang bergerak untuk melakukan suatu aktivitas dan perubahan secara global. Motivasi lahir karena didorong oleh usaha pemenuhan kebutuhan manusia yang bertingkat. Jhon B. Miner, mengatakan bahwa secara psikologis, manusia yang termotivasi akan semakin meningkatkan aktivitas kerjanya (Miner, 1990: 21).

Pendidikan Islam di Indonesia telah berlangsung sejak masuknya Islam ke Indonesia (Hasan, WA, 21 Juni 2018). Pada tahap awal pendidikan Islam dimulai dari pertemuan pribadi maupun kelompok antara muballigh dengan peserta didiknya. Setelah komunitas muslim terbentuk di suatu daerah, mulailah mereka membangun masjid, surau atau langgar yang difungsikan sebagai tempat ibadah sekaligus tempat pendidikan, begitu juga dengan rumah para kyai, disamping sebagai tempat tinggal, juga tempat pendidikan. Setelah itu muncullah lembagalembaga pendidikan lainnya seperti pesantren, rangkang, dayah, sampai kepada 


\section{Pembaharuan Sistem Pendidikan Pesantren dan Strategi Bertahannya, Menuju Pesantren Idaman Masa Depan dalam Menghadapi Tantangan Globalisasi}

Husnul Amin

madrasah dan sekolah. Materi yang disampaikan mulai dari belajar membaca kitab suci Al- Qur'an sampai kepada kitab-kitab klasik. Bahkan berkembang terus sampai dijadikan sebagai tempat memecahkan berbagai persoalan yang mereka hadapi dalam kehidupan sehari-hari. Keadaan seperti ini bertolak belakang dengan pendidikan sekuler yang dikembangkan penjajah yang tidak sama sekali mengajarkan ilmu agama di sekolah-sekolah pemerintah, sehingga terpolanya pendidikan di Indonesia ketika itu dengan dua sistem yang kontras (Haidar, 2007: 2).

Bertolak dari penjelasan di atas, diyakini bahwa pesantren merupakan lembaga pendidikan Islam tertua di negeri ini, yang masih tetap eksis memberikan jasa dan konstribusinya yang riil bagi pembangunan bangsa dan negeri ini. Pada masa perjuangan kemerdekaan, pesantren merupakan benteng pertahanan bangsa yang sangat kokoh dalam menghadapi serangan penjajah, banyak tokoh-tokoh pejuang nasional yang berasal dari kalangan ulama dan santri pondok pesantren, seperti Imam Bonjol, Pangeran Diponegoro, Teuku Umar, Cut Nyak Dien, Arraniry, Syaikh Nawawi al Bantani, KH. Hasyim Asyári, KH. Ahmad Dahlan, dan lain-lain.

Bahkan sampai saat ini, di samping pondok pesantren masih tetap hadir sebagai lembaga kaderisasi umat, agen perubahan, dan benteng pertahanan mental moral bangsa dari invasi budaya asing serta global yang bertentangan dengan nilainilai luhur bangsa (Wafa, 2006: 1). Juga pesantren sebagai salah satu benteng pertahanan umat Islam, pusat dakwah dan pusat pengembangan masyarakat muslim Indonesia (Abdullah, dkk, 2020: 99). Karena pesantren adalah lembaga yang bergerak di bidang pendidikan, maka dituntut untuk membenahi dirinya agar menjadi sebuah institusi pendidikan modern yang siap berkompetisi dan bersaing dengan lembaga-lembaga pendidikan lainnya.

Pasca kemerdekaan tantangan pesantren semakin tampak jelas dan terus berlanjut sampai pada era globalisasi di mana teknologisemakin maju dan tantangan pesantren semakin berat. Perkembangan ilmu pengetahuan dan teknologi, sistem informasi, dunia kerja, isu-isu demokrasi, hak azasi manusia, jender, multikulturalisme sampai isu-isu lain, itu semua menjadi tantangan yang perlu dijawab dan disikapi dunia pesantren agar tetap eksis dan survive di tengah derasnya arus global sekarang ini (Jamali, 1999: 142-143). Oleh karena itu, dinamika pesantren masa depan tidak bisa dipisahkan dari proses globalisasi. Sebaliknya justru eksistensi pesantren masa depan sangat ditentukan oleh kemampuannya berintegrasi secara kultural dengan sistem internasional yang ditandai dengan tata hubungan yang semakin rasional, dinamis, dan kompetitif. Maka jelas, bahwa keniscayaan untuk mengadakan pembaharuan dalam berbagai macam aspek tidak bisa ditolelir lagi bagi pesantren sebelum mengetahui lebih jauh peluang atau kemungkinan pesantren menjadi "centre of excellence" bagi pengembangan sains dan teknologi (Mastuhu, 1999: 277-280). Lantas bagaimanakah strategi pesantren agar tetap eksis dan bertahan di era globalisasi sehingga menjadi pesantren Idaman Masa Depan. 


\section{Pembahasan}

\section{Pembaharuan Sistem Pendidikan}

Untuk mengetahui suatu pembaharuan yang terjadi perlu ditetapkan lebih awal indikator yang melekat pada pembaharuan itu. Suatu pembaharuan selalu mengikuti derap langkah dinamika kehidupan masyarakat. Hal ini berarti adanya pembaharuan merupakan hal yang tak terhindarkan sebagai konsekwensi logis dari adanya perubahan kompleksitas dari tuntutan kehidupan masyarakat yang majemuk.

Pada era globalisasi, pondok pesantren dihadapkan pada beberapa perubahan sosial budaya yang tidak terelakkan, pondok pesantren tidak dapat melepaskan diri dari perubahan-perubahan. Kemajuan teknologi informasi dapat menembus benteng budaya pondok pesantren. Dinamika sosial ekonomi telah mengharuskan pondok pesantren untuk tampil dalam persaingan dunia pasar bebas (free market), belum lagi sejumlah perkembangan lain yang terbungkus dalam dinamika masyarakat yang juga berujung pada pertanyaan tentang resistensi (ketahanan), responsibilitas (tanggung jawab), kapabilitas (kemampuan), dan kecanggihan pondok pesantren dalam tuntutan perubahan besar. Apakah pesantren mampu menghadapi konsekuensi logis dari perubahan-perubahan tersebut.

Usaha mencari alternatif jawaban itu relatif akan ditemukan bila Strategi Pengembangan Pondok Pesantren dalam Era Globalisasi diketahui dan dipahami secara persis antropologi internal dan eks- ternal pondok pesantren (Syafa'at, 246). Azyumardi Azra berpendapat bahwa dalam merespon tantangan zaman pesantren senantiasa melakukan berbagai pembaharuan yang salah satunya adalah refungsionalisasi pesantren menjadi pusat pembangunan masyarakatsecara menyeluruh sehinggapesantren menjadialternative pembangunan yang berpusat pada masyarakat itu sendiri(people centered development) sekaligus sebagai pusat pengembangan pembangunan yang berorientasi pada nilai (value-oriented development) (Azra, 2002: 105). Dalam kondisi ini pesantren diharapkan dapat menjadi pusat pemeliharaan lingkungan hidup, pusat pemberdayaan ekonomi masyarakat dengan membuka berbagai vocational seperti agribisnis yang mencangkup peternakan, pertanian, perkebunan, kehutanan dan juga mengembangkan usaha industri rumah tangga/industri kecil.

Di samping itu, pembaharuan sistem pendidikan harus juga dilakukan, baik dengan menyertakan satu atau bahkan beberapa aspek yang akan diperbaharui. Hal itu pada umumnya tergantung dari latar belakang dan tujuanyangdilakukannyapembaharuantersebut oleh lembaga penyelenggara pendidikan. Makadalam proses pendidikan terjadi pembaharuan pendidikan dalam berbagai aspek. Misalnya; pembaharuan dalam aspek tujuan pendidikan, aspek kelembagaan pendidikan, aspek pendidik, aspek peserta didik, aspek materi/kurikulum, aspek metode pendidikan, aspek lingkungan pendidikan (milieu), aspek evaluasi pendidikan, dan aspek manejemen pendidikan (Thaib, 2010: 5). 


\section{Pembaharuan Sistem Pendidikan Pesantren dan Strategi Bertahannya, Menuju Pesantren Idaman Masa Depan dalam Menghadapi Tantangan Globalisasi}

Husnul Amin

\section{Aspek-Aspek Pembaharuan \\ a. Pembaharuan Aspek Tujuan}

Pada komponen ini, Tujuan pesantren harus ada sebelum melangkah untuk mengerjakan sesuatu. Bila pendidikan dipandang sebagai suatu proses, maka proses tersebut akan berakhir pada tercapainya tujuan akhir pendidikan (Arafiin, 1987: 119). Maka usaha yang tidak mempunyai tujuan tidaklah mempunyai arti apa-apa. Berbicara tentang tujuan pendidikan maka erat kaitannya dengan tujuan hidup manusia, karena pendidikan hanyalah sebagai alat yang digunakan manusia untuk memelihara kelanjutan hidupnya, baik sebagai individu maupun sebagai masyarakat. Oleh karena itu, tujuan pendidikan pesantren harus diarahkan sesuai dengan kebutuhan dan tuntutan yang sedang dihadapi (Langgulung, 1995: 147).

Pembaharuan dalam aspek tujuan pendidikan di sini adalah suatu perubahan baru terhadap tujuan pendidikan yang sengaja dilakukan oleh Pesantren untuk dapat maju dan berkembang dalam rangka menjawab tuntutan masyarakat yang selalu berubah dan sesuai dengan kondisi zaman serta kompetitif ditengah-tengah globalisasi.

\section{b. Pembaharuan Aspek Organisasi}

Keberadaan pesantren dimanapun, pasti memiliki ciri tersendiri dan keistimewaan khusus, demikian pula pada aspek organisasinya, dimana pesantren memiliki struktur organisasi yang sudah pasti berbeda antara yang satu dengan yang lain sesuai dengan kebutuhan masing-masing, namun juga tidak dapat dipungkiri bahwa masing-masing pesantren juga memiliki kesamaan-kesamaan yang menjadi ciri umum struktur organisasi pesantren dan tampak adanya kecenderungan perubahan yang sama di dalam menatap masa depannya.

Pembagian kerja antar unit-unit kerja sering kali kurang tajam dan banyak terdapat kesamaan. Misalnya antar unit yang mengurusi pendidikan dan pengajarandengan unit yang mengurusi pengajian,kehumasan, kemasyarakatan, kesantrian, dan sebagainya sering kali mempunyai tugas yang sama. Seperti sama sama mempunyai program mengadakan pengajian, mengerahkan santri untuk kerja bakti, memperbaiki jalanan, dan sebagainya. Namun tidak tampak adanya pertentangan atau konflik diantara unit-unit yang dimaksud, karena semua berlandaskan pada ketiga kata kunci tersebut, sehingga corak kerja dalam pesantren bersifat kekeluargaan dan lebih menekankan pada pentingnya human oriented dari pada target oriented.

Gaya kerja dalam struktur organisasi pesantren pada umumnya masih merupakan garis lurus keatas, artinya setiap unit kerja bergantung pada atasan langsung, keberhasilan kerja dalam struktur organisasi pesantren secara keseluruhan merupakan penjumlahan dari hasil masing - masing unit kerja, hubungan kerja antar unit kerja bersifat co-acting bukan inter-acting. Hubungan kerja yang bersifat co-acting itu sama dengan keberhasilan kerja suatu tim bulu tangkis, 
Volume 4 Nomor 1 Edisi Juni 2019

P-ISSN : 2541-3686

dimana masing - masing partai bekerja sendiri - sendiri, jika di dalam suatu tim terdiri atas lima partai dan jika tiga dari lima partai telah menang, maka keseluruhan tim bulu tangkis tersebut telah menang. Keberhasilan tiap partai tidak tergantung pada partai yang lain, tetapi jumlah kemenangan partai menentukan kemenangan tim secara keseluruhan. Sebaliknya hubungan kerja yang bersifat interacting itu sama dengan keberhasilan kerja di bidang sepak bola, dimana keberhasilan setiap pemain sangat tergantung pada pemain yang lain, dan secara keseluruhan menentukan kemenangan kesebelasan sepak bola yang bersangkutan.

Kesimpulan akhir secara global, bahwa Kenyataan ini terjadi karena pendidikan sistem madrasah atau sekolah yang berjenjang memerlukan sistem kepemimpinan kolektif, karena kepemimpinan individual seorang kyai tidak memadai lagi.

\section{c. Pembaharuan Aspek Kurikulum}

Kurikulum pesantren secara signifikan berperan sebagai pedoman dan landasan operasional bagi implementasi proses belajar mengajar di kelas, lembaga pendidikan dan pelatihan. Hal tersebut diharapkan dapat menimbulkan perubahan tingkah laku, sekaligus alat dan sarana untuk mencapai tujuan pendidikan di pesantren.Bicara masalah pembaharuan kurikulum, maka erat kaitannya dengan kebutuhan manusia. Di mana kebutuhan manusia terus berubah, bertambah, dan dinamis sesuai dengan tuntutan masa. Kalau ingin kurikulum sesuai dengan kebutuhan dan tuntutan masa, maka seyogyanya diadakan pembaharuan terusmenerus (Tarigan, 1993: 135).

Pembaharuan kurikulum dilakukan karena kurikulum adalah suatu yang bersifat dinamis dan mengikuti perubahan nilai-nilaibudaya masyarakat sesuai arus perkembangan IPTEK. Artinya, kurikulum sebagai alat untuk mencapai tujuan pendidikan selalu menyesuaikan dengan perkembangan masyarakat yang selalu berubah. Kurikulum dibuat mesti bermanfaat bagi siswa dan membantu menyelesaikan masalah mereka dan masalah masyarakat. ${ }^{1}$

Sejalan dengan alur ini, maka pembaharuan kurikulum dapat ditandai dengan adanya mata pelajaran baru yang diperkenalkan. Atau dapat pula berupa perubahan jam dan mata pelajaran, baik dalam bentuk penambahan maupun pengurangan sesuai dengan kebutuhan zaman.

\section{d. Pembaharuan Aspek Metode Pembelajaran}

Proses pendidikan terjadi dalam lingkungan interaksi edukatif antara guru dengan murid melalui metodologi. Pembaharuan metodologi berakar pada kenyataan bahwa tidak ada metode mengajar yang lebih baik dan efektif karena setiap metode memiliki kelebihan dan kekurangan. Oleh karena itu, metode yang digunakan dalam pengajaran sebaiknya tidak terbatas pada satu metode atau

\footnotetext{
${ }^{1}$.Kurikulum harus terbuka, kemungkinan akan adanya peninjauan, fleksibel, dapat direvisi dan dievaluasi setiap saat sesuai dengan kebutuhan setempat. Sehingga, penerapan kurikulum tersebut dapat mengembangakan minat, kreativitas, produktivitas, dan merangsang perubahan psikologis peserta didik. Disamping itu, dapat pula mengembangkan aspek kognitif dan psikomotor peserta didik dalam rangka pengembangan dan pembentukan kepribadiannya (Al-Toumy, t.th: 528-529).
} 


\section{Pembaharuan Sistem Pendidikan Pesantren dan Strategi Bertahannya, Menuju Pesantren Idaman Masa Depan dalam Menghadapi Tantangan Globalisasi}

Husnul Amin

beberapa metode saja, tapi harus disesuaikan dengan kondisi santri dan pelajaran yang disampaikan sehingga metode yang digunakan dapat mewujudkan tujuan pendidikan dengan baik.

\section{e. Pembaharuan Aspek Pendidik/Pengelola/SDM}

Pendidik merupakandi antara komponen pendidikan yang harus diperhatikan. Karena pendidik bertanggung jawab dalam pembentukan pribadi santri. Seorang pendidik tidak hanya berfungsi sebagai pengajar di kelas saja, melainkan harus mampu menciptakan suasana pergaulan yang edukatif di luar kelas. ${ }^{2}$ Pendidik juga memberi kesempatan kepada perserta didik untuk melakukan berbagai kegiatan guna memecahkan masalah (how to think bukan what to think).

Pembaharuan pendidik berorientasi pada peningkatan mutu pendidik yang dapat ditandai dengan adanya usaha dalam pencapaian kompetensi yang melekat pada diri seorang pendidik. Usaha pembaharuan pendidikan ditujukan untuk kepentingan siswa atau peserta didik, yang sering disebut "Student Centered Approach" (Hasbullah, 2005: 202). Pembaharuan tersebut berorientasi untuk menghasilkan sosok peserta didik yang ideal. Seperti; berkualitas, professional, mumpuni dibidangnya, berkemauan keras atau pantang menyerah, memiliki motivasi yang tinggi, sabar, tabah, tidak mudah putus asa, berdaya saing dan lain sebagainya.

\section{f. Pembaharuan Aspek Peserta Didik}

Upaya ini dapat dilakukan dengan cara membenahi proses pendidikan. Artinya, pembaharuan terhadap santri berawal dari pembaharuan terhadap in-put (calon santri yang akan masuk) lewat penyeleksian yang ketat. Lalu, dilakukan penggodokan dan pemantapan keilmuan dalam kegiatan belajar mengajar (proses) di sekolah dan di asrama untuk menghasilkan out-put yang diharapkan.

Dari beberapa penjelasan di atas tentu pembaharuan sangat urgen bagi pesantren, di mana dengan upaya pembaharuan, pesantren akan menjadi eksis, servive berdaya saing dan dengan sendirinya ia akan menemukan strategi untuk untuk siap menghadapi tantangan globalisasi.

\section{Pesantren Idaman}

Potret pesantren idaman yang ditulis di bawah ini,adalah merupakan hasil analisis mendalam dari sebuah jurnalyang terfokus pada ciri-ciri pesantren eksis dan bertahan dalam menghadapi tantangan globalisasi, namun tidak menutup kemungkinan peserta seminar dapat menambah ciri-ciri lain, karena ciri-ciri berikut ini hanya hasil ijtihad, antara lain: 1) Pesantren telah mengakar di masyarakat, 2) Kyai menjadi figur teladan,3) Menyelenggarakan paket pendidikan yang lengkap dengan basis pendidikan agama dan umum dalam

${ }^{2}$.Disamping itu, seorang pendidik juga memiliki pribadi yang berjiwa luhur dan bekerja penuh pengabdian. Mereka terus-menerus memberikan jasa-jasa tanpa mengharapkan imbalan dari pesertaq didik. Departemen Pendidikan dan Kebudayaan, Guru Pahlawan Nasional Tanpa Tanda Jasa, 1984: 14). 
P-ISSN : 2541-3686

rangka pembinaan dan pendampingan kecerdasan intelektual, emosional serta spiritual. 4) Menyelenggarakan kegiatan keterampilan yang berorientasi pada penyaluran dan pengembangan minat-bakat. 5) Penerapan manajemen modern dalam pengelolaan pesantren, 6) Penerapan sistem sentralisasi dalam penyelenggaraan kegiatan pesantren dan pendidikan. 7) Penerapan manajemen keuangan sentral untuk operasional biaya penyelenggaraan kegiatan pesantren dan pendidikan. 8) Keterlibatan pengelola pesantren pada kegiatan sosialkeagamaan dan sosial politik. 9) Kepercayaan pemerintah dan swasta yang turut serta dalam upaya pengembangan pesantren, termasuk peningkatan pendidikan yang dikelola pesantren. 10) Mempunyai ikatan kuat dengan alumni dan wali santri yang terorganisir dalam penyelenggaraan kegiatan sosial. 11) Mempunyai usaha pereokonomian dalam mendukung eksistensi pesantren berupa koppontren (koperai pesantren) yang bersifat layanan jasa kepada santri dan masyarakat (Syafa'at, dkk, 2014: 245-269).

\section{Strategi Bertahannya Pesantren Tradisional}

Ini adalah di antara hasil analisis penelitian yang pernah dilakukan terhadap pesantren-pesantren tradisional tahun 2011, bahwa pesantren akan bisa bertahan jika melakukan langkah-langkah berikut:

a. Pesantren Akan bertahan jika menyelenggarakan pendidikan formal, yang bisa membiayai penyelenggaraan pendidikan tradisionalnya.

b. Pesantren tradisional akan dapat bertahan bila menyelengarakan perguruan tinggi (Izin Operasional Pemerintah) yang bisa menampung lulusannya.

c. Pesantren Tradisional akan bertahan bila ia mampu berwiraswasta dan sekaligus memberi pelatihan santri kewiraswastaan/life skill.

d. Pesantren tradisional akan bertahan jika mampu memberikan santrinya ijazah formal.

e. Pesantren tradisional akan bertahan, bila mampu menghantarkan alumninya menguasai social sains.

f. Pesantren Tradisional akan bertahan jika ijazahnya terakreditasi (Amin, 2011). 
Pembaharuan Sistem Pendidikan Pesantren dan Strategi Bertahannya, Menuju Pesantren Idaman Masa Depan dalam Menghadapi Tantangan Globalisasi

Husnul Amin

\section{Simpulan}

Sebagai penutup dari makalah singkat ini, bahwa masih banyak lagi komponen pendidikan di pesantren yang harus dibahas dan perlu pembaharuan,namun karena keterbatasan waktu, maka perlu direkomendasikan agar peserta seminar membaca secara individu komponen-komponen pendidikan pesantren yang sesungguhnya tidak terbatas, karena pesantren menganut sistem pendidikan 24 jam. Disadari atau tidak,sesungguhnya di antara kunci bertahannya pesantren dan stategi untuk tetap eksis dalam menghadapi tantangan globalisasi adalah pembaharuan terhadap aspek atau komponen pendidikannya. Wallahu 'Alam Bisshowab.... 


\section{DAFTAR PUSTAKA}

Azra, Azyumardi, 2002. Paradigma Baru Pendidikan Nasional , Jakarta, Kompas.

-------,2002.Pendidikan Islam, Tradisi dan Modernisasi Menuju Milenium Baru, Jakarta, Logos Wacana Ilmu.

--------,2002. Pendidikan Islam, Tradisi dan Modernisasi Menuju Milenium Baru, Jakarta, Logos Wacana Ilmu, 2002 , cet. Ke-4

Abraham Maslow,1994. Motivasi dan kepribadian, terjemahan Nurul Iman, (Jakarta: Pustaka Bunamas Pressindo, 1994), cet. Ke-4.

Bruinessen, Van, Martin, 1995. kitab Kuning ; Pesantren dan Tarekat ; Tradisi-Tradisi Islam di Indonesia, Bandung, Mizan, cet. Ke-1.

Bawani, Imam, 1993 .Tradisional Dalam Pendidikan Islam, Surabaya : al - Ikhlas.

Dhofier, Zamakhsyari, 1982. Tradisi Pesantren, Studi Tentang Pandangan Kyai, Jakarta. LP3ES.

--------, 1984. Tradisi Pesantren ; Studi tentang Pandangan Hidup Kiai, Jakarta ; LP3ES.

Dirdjosanjoto, Pradjarta, 1999. Memelihara Umat : Kiai Pesantren - Kyai Langgardi Jawa, Yogyakarta: LKI

Haidar, 2007. Sejarah Pertumbuhan dan Pembaharuan Pendidikan Islam di Indonesia, (Jakarta : Kencana )

Haedari, Amin, 2005. Masa Depan Pesantren Dalam Tantangan Modernitas danTantangan Kompleksitas Global, Jakarta.

Jabali, Fuad, 2006. Membangun pesantren di ranah sunda: Belajar dari darul arqam, dalam Jajat Burhanudin dan Dina afrianty, mencetak muslim modern, peta pendidikan islam Indonesia, jakarta: PT raja Grafindo persada.

Jamali, ( ed ). 1999. Kaum Santri dan Tantangan Kontemporer,Pesantren Masa Depan, Wacana Pemberdayaan dan Transformasi Pesantren, Bandung, Pustaka Hidayah.

Madjid, Nurcholis,1997. Bilik - Bilik Pesantren : Sebuah Potret Perjalanan, Jakarta : Paramadina

Mastuhu, 1994. Dinamika Sistem Pendidikan Pesantren, Suatu Kajian Tentang Unsur dan Nilai Sistem Pendidikan Pesantren, Jakarta, INIS.

Mas'ud, Abdurrahman,(ed),2007. Budaya Damai Komunitas Pesantren, Jakarta, Pustaka LP3ES.

--------, 2007. Intelektual Pesantren , Jogjakarta, LKIS, , cet. Ke-1.

Masyhud, Sulthan et. al, 2003.Manajemen Pondok Pesantren, Jakarta ; Diva Pustaka. Agung. 
Pembaharuan Sistem Pendidikan Pesantren dan Strategi Bertahannya, Menuju Pesantren Idaman Masa Depan dalam Menghadapi Tantangan Globalisasi

\section{Husnul Amin}

Rahardjo, Dawam, M. (ed), 1985. Pergulatan Dunia Pesantren, membangun dari bawah, Jakarta ; P3M, , cet-1.

Saridjo, Marwan, 1979..Sejarah Pondok Pesantren di Indonesia, Jakarta : Dharma Bhakti.

Thaib BR, M.amin, .Gerakan Pembaharuan Pendidikan Islam di Indonesi, (Jakarta: Balai Penelitian dan Pengembangan Agama)

Undang - Undang Republik Indonesia nomor 20 tahun 2003 tentang Sistem Pendidikan Nasional pasal 30 ayat 1,2,3,4 dab 5, Jakarta, Fokusmedia, 2006

Wafa, Tol 'at,2006. Peranan Pondok Pesantren dalam Menghadapi Tantangan Global, Makalah seminar alumni pondok modern Dar Assalam Gontor Ponorogo

Wahid, Aburrahman ( ed). 1987. Pesantren dan Politik Masa Kini, Jakarta, P3M.

Wahjoetomo, 1997. Perguruan Tinggi Pesantren, Pendidikan Tinggi Alternatif Masa Depan, Jakarta : Gema Insani Press.

Wahid, Abdurrahman, 2003. Menggerakan Tradisi, Esay-Esay Pesantren,

Yogyakarta, LKIS.

Ziemek, Manfred,1985. Pesantren dalam Perubahan Sosial, terjemahan Butche B. Soendjono, Jakarta : LP3M. 